\title{
The Deficient Concept Of The Tourist In Spanish Regional Legislation On Tourism Management
}

\author{
Antonio Villanueva-Cuevas, University of Castilla-La Mancha, Spain
}

\begin{abstract}
In Spain, the Autonomous Regions have exclusive responsibility for tourism matters and, given this fact, they have adopted general management and regulation laws to govern the sector. These laws have different names but all include the term "tourism" in their titles. Therefore, the concepts of "tourism" and "tourist" are essential for understanding the scope of their application. However, if one studies the content of these laws, they will see that very few of them actually define "tourism" and, more importantly, that the definitions of "tourist" do not correspond to the traditional and historical meaning of this term. The conclusion the author has come to is that said laws regulate tourism only from a partial, limited perspective as a simple lending/receiving of services, especially of private natural areas, and that they make very few references to quality, sustainability and competitiveness as guidelines that are required to spell out a modern concept of tourism.
\end{abstract}

Keywords: Tourism; Tourist; Environment; Public Services

\section{INTRODUCTION}

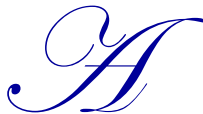

rticle 148.1, Section 18 of the 1978 Spanish Constitution assigns exclusive responsibility to the Autonomous Regions in matters of "promotion and management of tourism within their borders". This has led to the development of extensive legislation, the aim of which is the general regulation of tourism within each given region. This legislation generally features wide-sweeping generic titles, and, as such, the laws are known as "tourism management", "tourism regulation" or even "tourism" laws. This lack of specification leads us to believe that the intent of these laws is to serve as wide-sweeping general legislative codes in the said sector.

Nevertheless, if one turns to the content of said laws, to a large extent, this initial interpretation can be narrowed down. In fact, it is curious, to say the least, that of all of the autonomous regulations that have defined themselves as "tourism" management laws, only two expressly define their material regulatory scope. Their accuracy may be greater or lesser, but at least they make reference to the social reality that has led to the guidelines they contain (specifically, Law 6/2003, from 27 February, on tourism management in Aragon, Article 2, letter f; and Law 2/2001, from 31 May, on tourism management in La Rioja, Article 2, letter a). All other Autonomous Regions claiming an alleged difficulty for articulating the definition, or simply claiming a lack of necessity for doing so, opt for defining a group of individuals, businesses, establishments, resources and activities, all related to tourism, but without being exact about their use of the adjective. In this way, they define and regulate the content of the subject, but not the larger concept.

However, in alleging difficulty for finding an adequate definition of tourism, they are actually hiding the true motives behind the laws. According to the legislation, all activity involving people and the consequences thereof (basically economic in nature) is tourism. Their aim is to cover the entire travel and hotel market in their area with an interest that is purely commercial and statistical, thus continuing with the pre-constitutional tradition in which the most important issues were the bottom line, quantitative growth and not getting caught up unnecessarily 
in other nuances. But this approach brings with it, on the one hand, a vision that is clearly partial to this phenomenon, which may be most interesting to Public Entities, especially in times of economic crisis, but which in some way predicts the many kinds of relationships that generate tourism without taking a close look at it. On the other hand, it goes beyond the idea of tourism and includes motives that can, in some way, be considered to be part of tourism (such as professional motivations), which results in a true distortion of this concept. In addition, such a limited perspective of tourism regulation, as nothing more than giving/receiving tourist services through channels that are usually private, keeps regional legislation from providing adequate solutions and being able to respond to the implementation of a new tourism development model provided by the European Union and the most widely supported position and makes it impossible for tourism to be rooted in quality and sustainability as criteria for maintaining and increasing competitiveness in the Spanish tourism sector.

This conclusion is even more striking if analyzing one of the elements as it relates to the services that these laws aim to regulate - the tourist - which, in the author's opinion, is the real justification for the existence of said laws, which, as shall be seen, is not reflected in their content.

\section{The Erroneous Definition Of "Tourist” In Spanish Legislation On Tourism Management}

After analyzing historic Spanish regulation in matters of tourism, the first thing that must be noted is the lack of definitions for the term "tourism" found in our legal tradition. Focusing on this term, and also "tourist", it might be said that "our legislative body was slow in establishing the term, initially limiting itself to nothing more than an employee that is more or less a reiteration of the term, but without providing a definition" (FERNÁNDEZ ÁLVAREZ, 1974).

It would be the Royal Decree of October $6^{\text {th }}, 1905$ that would create the National Commission for promoting the artistic and recreational travels of foreigners in Spain. In its Preamble, the Decree used the words "tourism" and "tourist", while alluding in the operative provisions to the concepts of "travelers" and "travels", "with a character that is markedly cultural" (ROCA ROCA, CEBALLOS MARTÍN and PÉREZ GUERRA, 1998). Later, the term "tourism" was used repeatedly, "especially following the creation by Royal Decree \#745, from April $25^{\text {th }}$, 1928, of the National Tourism Association, but always with implicit value, which is to say, without defining Tourism" (FERNÁNDEZ ÁLVAREZ, 1974).

It would not be until 1963 , in the Preamble to the Law $48 / 1963$ of July $8^{\text {th }}$ on Tourism Skills, that the definition for "tourism" would be provided, indicating that "it is the movement and stay of people away from their normal place of work or residence for motives that are not professional in nature", and implying the definition of "tourist" that has since derived. That definition of tourism is criticized by academics for its excessively broad scope, especially because no time limits are established for the movement or stay (FERNÁNDEZ ÁLVAREZ, 1974; CEBALLOS MARTÍN, and PÉREZ GUERRA, 1998), but it is accepted because it contains the three elements that identify the notion of tourism - movement of people around areas other than their normal place of residence, stays away from their normal places of work or residence, and having motives other than those normally associated with professional obligations (ROCA ROCA, CEBALLOS MARTÍN, PÉREZ GUERRA, 1998; LUENGO YUSTE, 1992).

Continuing with the evolution of the law, the Spanish Constitution of 1978 makes clear reference to the term "tourism" only when it allocates powers in this matter between the State and the Autonomous Regions, and logically, it does not provide definitions for the utilized terms. Still, as a consequence of the distribution of powers articulated by the document itself, tourism matters have fallen almost entirely to the Autonomous Regions that have enacted the corresponding general laws on tourism regulation and management, as stated above, and which provide interesting new (not entirely accurate) information with respect to the definition of "tourist".

\section{The Confusion Between The Definitions Of "Tourist" And "Tourist User"}

A detailed study of the regional law on general tourism management is key for determining the significance of the concepts "tourism", "tourist" and other related terms, given that said law contains the current legal regulation for the Spanish tourism sector. It outlines said sector in its respective territorial areas, as a reflection of the regional 
powers in these matters, and these are the norms that are primarily applicable. Further, in order to determine the application of the laws, the principle criteria used are the conceptualization and delimitation of a series of subjects, activities, businesses, establishments and goods that are considered to be related to tourism, thus allowing us to predict that the regulations will clarify what must be understood by the analyzed terms.

In other words, regional regulations on tourism management will be applicable when they are in the presence of certain specific subjects, matters, professionals, or even of goods, and the law that regulates this entire grouping of aspects must be equally specific - the regional laws on tourism management cited above. To this end, in the author's opinion, the definition of these terms is the essential element for determining the concept of tourism in said regional law, which will justify how the sector is treated and, ultimately, if the tourism development model is consistent with the prerequisites of quality and sustainability as the path to competitiveness in different areas and a form of public action, in this matter, based on the overall, integral and inclusive handling of tourism.

In addition, this has been brought about by said regional tourism management laws through the establishment of a general area of application, and if differences can be observed between them when determining said area - some Autonomous Regions lay these out in great details, while others make more sweeping generalizations, their content all makes reference to the same element - "the grouping of subjects (public and private), actions and resources that make up the tourism sector" (Article 2 of Law 7/2001, from June 22 ${ }^{\text {nd }}$, on tourism management in Asturias). Later, they provide concrete definitions of those tourist subjects, actions and resources.

For all of these reasons, and without further delay, the author believes it is necessary to begin indicating that a definition of the term "tourist" in regional laws governing tourism management should be imperative, as it affects the very existence of said laws. Tourists are the axis at the center of these regulations because, in essence, what they seek is the development and empowerment of an economic sector that can only increase its income by augmenting tourist flow or ensuring that tourists spend more money during their stay. To this end, it has become necessary to establish certain minimum levels of quality and assurance in the services required by tourists, establishing a series of conditions for carrying out activities and a penalty system for those who fail to meet these requirements. Further, the tourism resources in each territory must be made known to potential visitors through corresponding promotional activities. These two aspects make up the backbone of all of the regional laws that regulate tourism in such a way that, in essence, tourists are the main reason for and the ultimate goal of the enactment of said regulations. For this reason, the author is of the opinion that tourists are key to tourism and its regulatory laws, in light of the fact that it is they themselves who determine the where, when, how and why behind their travels and what they do on their trips and during their stay. As such, a correct definition of "tourist" in regional law is absolutely necessary insofar as it is constituted in the qualifying condition that brings about the existence and application of said regulations (TUDELA ARANDA, 1996).

However, this manifest importance which, in the author's mind, can be defined has not been acknowledged by the regional regulations that have been analyzed. Only the Autonomous Regions of Aragon, Castilla y Léon and La Rioja provide exclusive definitions in the body of the regulations of the term "tourist", although they may be similar to the other regional laws that have been analyzed. That is to say, as consumers, if one considers them to be "people who use tourism-related establishments, facilities and resources or receive the goods and services offered by tourism-related businesses" (Article 2, letter g, from Law 6/2003, from February 27 ${ }^{\text {th }}$, on Tourism in Aragon) and among the other regional laws that have been studied, with the exception of those in the Canary Islands, Catalonia, Navarre and Andalusia (where the concepts of "tourist" and "tourist user" are used), none define the term "tourist". What is more and only very rarely, this term is used in the body of regional regulations. On the contrary, with the exception of Aragon, Castilla y León and La Rioja, all of them use and define the term "tourist user", and even "tourist", as "users" with no further specification (Article 2, Section 1, letter h, from Law 2/2011, from January $31^{\text {st }}$, on the development and modernization of tourism in Extremadura).

In this respect, while for some authors the substitution of the term "tourist" for "tourist user" in the regional legislation currently in place comes about because said legislation has changed the focus of its attention, formerly centered on tourism-related businesses and now centered on the tourist himself, "who should be taken care" (TUDELA ARANDA, 1996); for us, its purpose is to understand tourists only as service consumers (BOUAZZA ARIÑO, 2006). 
This definitely remains incomplete but is at least coherent with the virtually unique purpose of managing the activities of tourism-related businesses that govern the above regional regulations and with the consideration of the provision and consumption of services as the most relevant relationship that can be derived from the practice of tourism. In addition, a distortion of the concept of tourists allows for said laws to include people who, in the strictest sense, could not be defined as such. As shall be seen below, this line of argument achieves nothing more than the generation of confusion and inconsistency.

In order to understand this claim, one must begin by indicating that regional regulations define the concept of "tourist" (in the case of those that do) and that of "tourist user", or else treat them as similar terms. In this respect, merely comparing questions of terminology without relevance to this study, and putting forth an example, it is sufficient to reproduce the definition provided in Article 15, Section 1 of Law 7/1995, from April $6^{\text {th }}$, on tourism management in the Canary Islands, which "understands tourist users and tourists to be those who use tourism-related establishments and goods or receive the services offered by businesses of this type and as the clients who demand and enjoy these services". This provision has been chosen precisely because it is one of the few laws that define the terms "tourist" and "tourist user" interchangeably. In short, all of the regional laws which regulate tourism, in general, define "tourist" and "tourist user" as those people who utilize tourism-related goods or demand, enjoy, and receive services from tourism-related businesses.

For this reason, the primary consequence that can be concluded from said definition is that it has been crafted from an unambiguous perspective in which the tourist is a consumer of a series of goods and services, thus justifying the use of the term "tourist user or consumer". In essence, we are facing a view of tourism that is purely commercial, where two clearly differentiated subjects appear - tourism-related businesses of all kinds, which organize and offer tourismrelated goods and services, and tourist users and tourists who are those that demand and utilize said goods and services.

This consideration is strengthened and better understood when one analyzes the systematic framing of the respective principles where "tourist user" is defined, almost totally immersed in the title or chapter that enumerates the rights and responsibilities in tourism matters, or that manages tourism-related activities in general, which is to say that it regulates tourism-related supply and demand as well as the business-user relationship that results from the practice of tourism. In this sense, it is logical that the adopted definition thinks of tourists as consumers. Further, from this point of view, and only initially, the scope of the definition may be sufficient, given that it allows for all those who utilize or enjoy tourism-related businesses and services to be considered "tourist users".

But, in the author's opinion, this understanding of the term is a distortion of reality, making the status of tourist unrecognizable. If the word "tourist" or even "tourist user" is used for any person, including year-round inhabitants, who eats in a restaurant on the beach, for example, or utilizes services on the beach or other similar services, it moves us further away from some of the most basic characteristics that determine the status of tourist, such as movement or a stay away from one's usual place of residence. These terms have been agreed upon by International Law at, for example, the International Conference on Travel and Tourism Statistics in Ottawa, held June 24-28, 1991, in which "tourist/traveler/visitor" was defined generally as "all people who move between two or more different countries or between two or more spots within their country of residence". One mustn't forget that at this International Conference a set of definitions was adopted which was later recognized by the General Assembly of the United Nations in their Ethics Code on matters of Tourism and approved by Resolution on December 21 $1^{\text {st }}, 2001$.

Furthermore, it may be correct to give the status of "tourist" or "tourist user" to those who are residents of a city and who go to a nearby village seeking leisure or entertainment, thereby becoming consumers of certain goods and services, but the same cannot be said of year-round residents who spend their leisure hours using the facilities and services offered by their city, which are addressed in legislation as related to tourism. In the author's judgment, this stretch cannot be made even for purely statistical reasons. If a person left the municipality of their residence for reasons unrelated to work, that would be sufficient to describe him as a tourist or tourist user, but if there is no movement at all, no matter how many tourism-related services they use in their place of residence, it would not be correct to classify them as tourists. 
What is more, as terms like "tourist" and "tourist user" become more common, the author believes that it is due to the fact that regional laws are using them incorrectly. If "user" is being modified by the adjective "tourist", this has the effect of narrowing down, within the generic set of all "users", those who present certain characteristics, specifically "tourism-related", which are limited only because they are using certain goods or services that are also labeled as being "tourism-related". In reality, what is happening in regional law is that when certain goods and services are labeled "tourism-related", the person who uses and enjoys them is labeled a "tourist user" or "tourist" when it is actually the reverse that is true. What is it that allows a good or service to be considered related to tourism? Simply, tourists are the people who overwhelmingly demand said goods and services. If these goods and services were used only by local residents, they would never be considered tourism-related and it would be tourist traffic that would determine demand for establishments and services that were truly given the status of being related to tourism. In short, tourists do not come into being because they are using an establishment, a business, a good or a resource related to tourism. On the contrary; these elements exist because they are requested, demanded, or visited by tourists.

As such, the author believes that regional regulations should not have used the term "tourist user" and should not have linked this term to that of "tourist". Instead, they should have used the term "user of tourism-related services", which would accurately describe the person who demands and utilizes certain goods and services that are qualified as being related to tourism, because the majority of their clients are tourists. Said concept would also make it possible to include people who cannot be qualified as such; for example, local residents who may use these goods and services from time to time. This interpretation is backed up by terminology used by Law 2/1999, from March 24th, on general tourism regulations in the Balearic Islands, which does not make reference to "tourist users", but rather to "users of tourism-related services", and by Law 2/2011, from January 31st, on the development and modernization of tourism in Extremadura, which refers to "user people". On the other hand, if one equates "tourist" with "tourist user" in the terms expressed in regional laws, the concept of tourist becomes too broad. All people could be considered "tourist users" (it would be enough to simply utilize the services of any tourism-related business) without possessing the characteristics that identify a "tourist" (movement, etc.).

In conclusion, the author is of the understanding that the best solution would have been to define "tourist" in a general sense, characterized by movement and a stay away from one's residence or workplace. Then the concept of "user of tourism-related services" or "user person" could have been more narrowly defined. The author considers this to be more correct than "tourist user", which makes special reference to the consumer aspect of the tourist and has the possibility of including all people, whether or not they are tourists, who use tourism-related goods, resources, businesses, or facilities, including local residents.

\section{The Importance Of The Concept "Assisted Tourist Population" Reflected In The Law 12/1999, From December $15^{\text {th }}$, On Tourism Management In Andalusia}

No differences or developments can be drawn from the definition of "tourist users or tourists" in Andalusia's law on tourism management, with respect to those offered in other regional laws. Still, as it regulates the tourist town in Article 6, it is understood that the goal of this declaration is to provide an adequate level of quality in the provision of public services to what is called the "assisted tourist population", which is defined as "that constituted by those who are not considered residents of the municipality but who are staying here temporarily for reasons related to tourism, a second home or tourist accommodations" (Section 3, Article 6).

In the author's opinion, in this concept, together with that of "visitor", the true definition of "tourist" is expressed. Although it is not referred to as such, it clearly lays out the elements that characterize a tourist - no residence in the municipality, but temporary stay or visit here, making a tourism-related visit, staying at a second home or tourist accommodations. It even seems to distance itself from the idea that the stay is motivated by entertainment, especially if one compares the previous concept to that of "visitor", as defined in the last paragraph of Article 2 of Decree 158/2002, from May 28 ${ }^{\text {th }}$, from the Regional Government of Andalusia. Here, regulation on tourist towns is developed, as predicted in the above-mentioned Andalusian law on tourism management, describing "the person who moves to a place other than his usual residence without accommodations in a tourism-related establishment, whose main motive for traveling is not related to paid work in the place he is visiting." Here, one can see that the difference between the two concepts is found in the type of accommodations and not in a tourism-related establishment. In reality, it has to do with the length of the stay. From there, one can appreciate the need to find 
accommodations or not (JÁIMEZ GAGO, 2010). The important element is not the motive for traveling, which would be overwhelmingly related to leisure and would, of course, be unrelated to work. As you can see, both concepts are used to define "tourist", with all its identifying characteristics.

The only problem with this definition is that it is only used for the regulation of tourist towns because, for the rest of the law, the term "tourist user" is utilized and is furthermore bound to that of "tourist". For the author, the reason for this differentiation is easy to understand. "Tourist user or tourist" is being identified strictly with those people who demand and utilize the generally private tourist infrastructure, which is an error also made by the rest of the regional tourism management laws. Basically, this understanding leads one to believe that there are no tourists other than the tourist users, which is to say that both parts of the legal consumer relationship are regulated businessman/user. On the contrary, the concept of "assisted tourist population"/"visitor" appears to be linked to the use and provision of public municipal services and, in accordance with the concept implemented by the regional legislation on tourism regulation, it cannot be said that anyone who makes use of public municipal services is a "tourist user", simply because these public services can somehow be considered "tourism-related" insofar as the local legislation does not regulate services of this kind. Rather, the opposite is true. The first consignee of public services is the ordinary resident, not the tourist, although in certain specific cases (in tourist towns) when the provision of these services is above a given level due to an influx of tourists, a distinction is made between "assisted tourist population" and "visitor" on the one hand, and "tourist user" on the other, as recognized in the Andalusian law.

As such, with due regard to the inconsistencies that can be derived when addressing the section of the law being studied, for the author and with all due corrections, the differentiation made in the Andalusian law between "tourist user/tourist" and "assisted tourist population/visitor" is the definition technique that should have been utilized by the regional legislation for regulation in this sector for addressing different criteria of definition according to the reality being defined. "Assisted tourist population/visitor" would be those people who temporarily move away from their usual place of residence motivated basically by leisure, likened to tourists and differentiating the two concepts according to length of stay, and "users of tourism-related services or user persons" (preferable to "tourist users" for the reasons stated above) are those who utilize the tourism-related goods, establishments, resources or infrastructures, which are normally private in nature, and who are overwhelmingly "assisted tourist population/visitor/tourists". This concept could also include all travelers not considered tourists; for example, those traveling for work-related reasons and even residents of the municipality who utilize tourism-related infrastructures. But it is clear that neither of these groups would even truly be tourists because they are either not moving about for reasons of leisure or reasons unrelated to work or because they are not moving away from their usual place of residence.

The mistake here, as has already been stated, lies in identifying "tourists" with "tourist users" and in defining both according to the demands or use they make of a tourism-related infrastructure. The specific characteristics of each term are quite different and, in this sense, the best solution in the case of the Andalusian law on tourism management would have been to identify "tourist" with "assisted tourist population" and not with "tourist user". Nevertheless, disregarding possible inconsistencies, the author believes that this distinction made by the Andalusian law, as discussed above, is fundamental in these matters and that it shows that it is, in fact, not at all complicated to lay out a correct definition of "tourist".

\section{CONCLUSION: The Vague Application Of Regional Laws On Tourism Management}

In closing, it might be said that the regional laws on tourism management include definitions of "tourist users or tourists" that are quite similar to one another and that, to the author's mind, are too partial and distort the concept of "tourist". They take the wrong approach in their attempt to adapt reality to that which they are trying to identify, which is to say, to the people who utilize private tourism-related infrastructures. The only variations that can be detected among the different regional regulations - beyond the mere wording of the definitions - are those that are related to terminology. Only Aragon, La Rioja and Castilla y León provide an exclusive definition for the term tourist; Murcia, Cantabria and Castilla-La Mancha, among others, refer strictly to the "tourism user"; the Balearic Islands speak of "users of tourism-related services"; the Basque Country uses broader language that alludes to "tourist users or clients"; and in the Canary Islands, for example, the law expressly refers to "tourist users" and 
"tourists". In any event, these terminological differences have no bearing on the analysis being carryied out. Only the allusion in the Balearic Islands to "users of tourism-related services" and in Extremadura to "user persons" could turn out to be interesting, as noted in the text relating to the interpretation made above, although the body of the law does not prove that this is the intention of these two autonomous regions.

In any case, one must remember the inaccurate nature of the regional laws on this point, arising from the extremely clear tendency toward the regulation of the private provision of the tourism-related services they make available. This would justify the partiality of the definitions of "tourist users or tourists" studied above that could be considered market- or business-related. A stricter concept of the term "tourist" is therefore necessary, one aspect of which would be key - its configuration as consumer, user and client of certain specific goods and services in the place they are visiting, therefore qualifying them as "tourism-related"; but this aspect alone would not be the identifying element of this concept.

In the author's opinion, this shortcoming is clearly relevant because, in reality, the regional laws do not correctly define the principle subjects that are the final recipient of its regulation and the people it aims to protect; namely, tourists, and which, for this reason, are called "tourism management or regulation" laws. For the protection of people who are not tourists, another law already exists, including those overseeing consumption, health and public safety. Tourism happens because tourists exist and it is they who demand a set of services when they engage in this activity. Tourists are the very essence of tourism, a past-time that exists because there are people who leave their places of residence for leisure purposes. Without the first element, the second would not exist and nor would the private sector that is charged with offering the services demanded by them. Although demand may be influenced, tourists must already exist who must be convinced of the advantages of one destination over another.

If, according to regional law, the "tourist user" is nothing more than one part of a legal consumer relationship, which is to say he is defined as a consumer of certain specific goods and services and, according to these laws, he is the same as a "tourist", what is the characteristic that distinguishes a tourist from a consumer? Is it necessary to individualize, in specific regulations, the rights and obligations of tourists aside from those already recognized as consumers and users? In fact, one of the justifications for these laws is the situation of a certain "helplessness" experienced by tourists when faced with the non-compliance of the obligations of businessmen, given that they are away from their normal place of residence, which complicates the guarantee of their rights. However, this circumstance cannot be appreciated in the articles of the regional laws. Actually, in the author's opinion, said laws do not contain the specificity of the "tourist user" with respect to general consumers.

In view of these circumstances, regional laws should evolve in the more open direction of the Andalusian law, differentiating between "assisted tourist population/visitor"- on the one hand, both of which are considered "tourists" and are classified by the duration of their stay, and "users of tourism-related services or user persons", on the other hand, which would center only on the quality of consumer of a set of specific goods and services, and where both tourists and other people who cannot be considered as such could be included, but with the common thread of being users of certain goods and services that are related to tourism. This conceptual discrepancy is not a problem and would lead to the clarification of the subjective scope of the application of the regional regulations of tourism management, thus avoiding confusion and duplication, and therefore, inefficiency.

\section{AUTHOR INFORMATION}

Antonio Villanueva Cuevas earned his Ph.D. in Law and Degree in Law at the University of Castilla-La Mancha. He is Assistant Professor in Public Law in the Public Law Department, Faculty of Social Sciences of Cuenca, at the University of Castilla-La Mancha (Spain). E-mail: Antonio.Villanueva@uclm.es.

\section{REFERENCES}

1. Bouazza Ariño, O. (2006): Ordenación del territorio y turismo (un modelo de desarrollo sostenible del turismo desde la ordenación del territorio). Atelier, Barcelona.

2. Fernández Álvarez, J. (1974): Curso de Derecho Administrativo Turístico. Ed. Nacional, Madrid.

3. Jáimez Gago, Mª I. (2010): Comentarios a la Ley del Turismo en Andalucía. Ed. Dykinson, Madrid. 
4. Luengo Yuste, J. (1992): Legislación Turística y Derecho Administrativo. Ed. Universitas S.A, Madrid.

5. Roca Roca, E., Ceballos Martín, Ma M., \& Pérez Guerra, R. (1998): La regulación jurídica del turismo en España. Universidad de Almería, Servicio de Publicaciones, Almería.

6. Tudela Aranda, J. (1996): "Hacia un nuevo régimen jurídico del turismo: la reciente legislación autonómica", RVAP, $n^{\circ} 45$. 